\title{
Zur Kenntniss des intermediären Kreislaufs der Gallensäuren.
} Von

\author{
Dr. med. Alrred C. Croftan,
}

Philadelphia, U.S.A.

Von den Gallensäuren (gallensauren Salzen), die aus dem Ductus choledochus in den Darm gelangen, wird ein grosser Theil wieder resorbirt. (Hoppe-Seyler, Bidder und Smith, Leyden, Naunyn, Vogel, Höne und Dragendorff, Tappeiner, Weiss, Prévost und Binet u. A.) Die vom Darme resorbirten Gallensäurenn werden dann wieder durch den Ductus choledochus ausgeschieden; in anderen Worten, sie beschreiben gewissermaassen einen intermediären Kreislauf von der Darmschleimhaut zur Leber.

Es fragt sich, welchen Weg schlagen die Gallensäuren in dieser Wanderung ein, und welche Functionen üben sie en route aus?

Tappeiner gelang es zur Zeit, nicht unbeträchtliche Mengen Gallensäure in der Lymphe des Ductus thoracicus zu finden. Da die Gallensäuren von hier naturgemäss in das Blut der Jugularis ergossen werden müssen, sollte man erwarten, dass sich auch im allgemeinen Blutstrom Gallensäuren normaler Weise vorfinden würden. Thatsächlich ist es jedoch bisher Niemandem gelungen, im Blute Gallensäuren aufzufinden. Bei der fundamentalen Wichtigkeit, die diese Frage in unserem Verständniss des sogenannten hämatogenen Iklerus einnehmen muss, abgesehen von dem rein physiologischen Interesse, das dieses Problem beansprucht, schien es der Mühe werth, noch einmal nachzusehen, ob sich am Ende doch nicht Gallensäuren in normalem Blute entdecken liessen.

Technisch begegnet man da bedeutenden Schwierigkeiten. Zunächst ist es bekannt, dass es oft gar nicht leicht ist, die Gallen. säuren quantitativ aus der Gallenflüssigkeit, wo sie ja reichlich vorhanden sind, $\mathrm{zu}$ isoliren. Dies rührt daher, dass man das Mucin der Galle zuerst ausfällen muss; die Gallensäuren haften mit ausserordentlicher Zähigkeit an diesem Mucin fest, so dass es oft nur nach 
langwierigen Manipulationen gelingt, Mucin rein und von Gallensäuren frei zu erhalten. Die Combination Mucin-Gallensäuren ist jedoch keineswegs eine chemische Verbindung, sondern eine rein mechanische Verkettung, denn durch anhaltendes Dialysiren lassen sich die zwei Substanzen trennen.

Andererseits weiss man, dass Gallensäuren stark giftige Eigenschaften besitzen; man könnte daher kaum erwarten, sie frei im Serum aufgelöst zu finden; viel eher könnte man, wenigstens hypothetisch, vermuthen, dass sie, wie andre toxische Körper, von den Leukocyten (Phagocyten) aufgenommen und von diesen durch den Blutstrom zu ihrer Destination getragen würden.

Diese beiden Möglichkeiten müssen daher bei der Suche nach Gallensäuren im normalen Blute in Betracht gezogen werden, nämlich dass sie entweder mit Proteïdkörpern des Blutes bei der Ausfällung, ähnlich wie bei der Isolirung aus Galle mit dem Gallenmucin, schwer trennbare Verb́indungen eingehen, die sie den Blutflüssigkeiten entreissen, oder dass sie im Leibe der Leukocyten verborgen (wieder möglicher Weise in Combination mit Proteïdsubstanzen) sich so der Entdeckung durch die gewöhnlichen Methoden entziehen.

Bedenkt man ferner, wie ninimal die in einem gegebenen Momente in einer kleinen Menge Blutes vorhandene Quantität Gallensäuren naturgemäss sein muss, so lässt sich leicht verstehen, warum es bisher noch Niemandem gelungen ist, in normalem Blute Gallensäuren aufzufinden.

Man muss erstens mit grossen Mengen Blutes arbeiten, zweitens mit Methoden, die die oben erwähnten zwei störenden Momente thunlichst eliminiren können.

Die Manipulationen, die zum Ziele zu führen versprachen, waren die folgenden zwei:

1. Grössere Quantitäten frisch gelassenen Blutes der künstlichen Verdauung auszusetzen. Da die Gallensäuren gegen die Einwirkung des Pepsins in saurer Lösung und des Trypsins in alkalischer Lösung bekannter Weise sehr resistent sind, so schien es möglich, dass alle störenden Proteïdsubstanzen gewissermaassen von den Gallensäuren wegverdaut werden könnten und die gallensauren Salze mithin nachher in der Lösung frei vorhanden sein würden.

2. Grössere Quantitäten frisch gelassenen Blutes mi aem vielfachen Volumen absoluten Alkohols zu behandeln. Hierdurch würden die Proteïdsubstanzen, sowohl des Serums als der Leukocyten, coagu- 
lirt und zu Boden geworfen werden, während die Gallensäuren sich in Alkohol auflösen müssten.

Diese beiden Methoden wurden angewandt mit dem Resultate, dass die erste Methode durchweg negative Resultate lieferte, die zweite dahingegen positive.

\section{Versuch 1.}

100 ecm frisch gelassenen Rinderblutes wurden schwach mit Essigsäure angesäuert und gekocht; von dem Eiweisscoagulat wurde abfiltrirt und der Rückstand wiederholt mit schwach essigsaurem kochendem Wasser nachgewaschen. Filtrat und Waschwasser wurden zur Trockne verdampft und der Rückstand secundum artem auf Gallensäuren untersucht. Es fand sich keine Spur, selbst die (allerdings nicht absolut gültige Furfurol-Reaction) fiel durchaus negativ aus. Der voluminöse Eiweissrückstand wurde gewogen, in zwei gleiche Theile getheilt und die eine Hälfte der Verdaunng mit künstlichem Magensaft (Pepsin-HCl) während zwei Wochen ausgesetzt, die andere Hälfte der Verdauung mit künstlichem Pankreassaft (d. h. TrypsinSodalösung in Chloroformwasser) ebenfalls während zwei Wochen ausgesetzt. In einer dritten Versuchsreihe wurde die tryptische Verdauung in einem Dialysator ausgeführt und die diffundirenden Verdauungsproducte von Zeit zu Zeit auf Gallensäuren untersucht. Es gelang jedoch niemals auch nur spurenweise Gallensäuren, weder unter den Producten der Pepsin- noch der Trypsinverdauung aufzufinden. - In Anbetracht des positiven Ausfalls der nächsten Versuchsreihe muss man daher annehmen, dass die kleinen, im normalen Blute vorhandenen Gallensäuren-Mengen doch nicht gegen andauernde peptische und tryptische Verdaung resistent sind.

\section{Versuch 2.}

$100 \mathrm{cem}$ Blut wurden durch eine Canüle, die in der V. jugularis eines Kalbes inserirt war, sofort in einen Liter absoluten Alkohols fliessen gelassen; die Mischung wurde während einer Minute energisch durchgeschüttelt und dann filtrirt; der rothbranne Niederschlag wurde mehrmals mit absolutem Alkohol durchgeschüttelt und schliesslich nach dem letzten Abfiltriren und Auspressen mit absolutem Alkohol ansgewaschen. Die alkoholischen Auszüge wurden auf ein kleines Volumen durch Abdestilliren des Alkohols gebracht und in dieser Lösung nach Gallensäuren gefahndet.

Der sehr verdünnte ursprüngliche Alkoholauszug gibt eine ganz definitive (Pettenkofer'sche) Furfurol-Reaction, die immer intensiver wird (mit dem gleichen Quantum Auszug angestellt), je concentrirter die Lösung wird.

Die Gegenwart von Gallensäuren wurde schliesslich auf folgende Weise definitiv festgestellt.

Der alkoholische Auszug wird auf etwa $100 \mathrm{cem}$, d. h. bis zur beginnenden Trübung verdampft, er enthält dann nur noch wenig Alkohol; dann mit destillirtem Wasser (100 ccm) verdünnt und aus 
der wässerigen Lösung nach dem Alkalisiren mit Ammoniak durch basisches Bleiacetat eine Fällung niedergeschlagen. Diese Fällung. muss alle etwa vorhandenen Gallensäuren enthalten. Die Fällung wird abfiltrirt und mit heissem absolutem Alkohol extrahirt. Die alkoholische Lösung wurde dann mit etwas Soda zum Trocknen verdampft nnd der Rückstand wieder mit absolutem Alkohol ausgezogen. - Diese alkoholische Lösung gibt eine sehr intensive FurfurolReaction, was allein schon sehr wahrscheinlich für die Gegenwart von gallensauren Salzen spricht, denn durch die Fällungsmethode, die ich angewandt habe, wird die Gegenwart aller andrer bekannter Substanzen, die die Furfurol-Reaction geben können, im letzten alkoholischen Auszug ausgeschlossen.

Setzt man zum Alkoholextract zwei Volumen Aether und lässt es eine Woche im Eisschrank stehen, so findet sich eine schwache Trübung und eine sehr geringe, kaum wägbare (mit $100 \mathrm{ccm}$ Blut) Menge Niederschlag. Filtrirt man die Spur feste Substanz ab und löst sie in $10 \mathrm{ccm}$ absolutem Alkohol wieder auf, so gibt diese Lösung wieder eine bestimmte, recht intensive Furfurol-Reaction. Betupft man schliesslich das blossgelegte Herz eines curarisirten Frosches mit einigen Tropfen der wässerigen Lösung einer Spur der Substanz (natürlich nach dem vorherigen Betupfen mit 1\% Atropinlösung, um die Vagus-Inhibition auszuschalten), so konnte eine auffallende Verlangsamung der Herzthätigkeit jedes Mal beobachtet werden.

Eine Krystallform konnte in der Spur Niederschlag nicht festgestellt werden. In einem späteren Versuche jedoch, in dem über ein Liter Blutes auf einmal verarbeitet wurde, erhielt ich 0,0042 g Cholate, die die typische Krrystallform (Platner) zeigten.

Es scheint daher festgestellt, dass im normalen Rinderblute Gallensäuren vorhanden sind. Es erübrigt noch za erörtern, ob sie im Serum, den rothen oder den weissen Blutkörperchen sich finden.

Serum und Blutkörperchen wnrden daher durch Centrifugiren von Oxalatblut getrennt und einzeln nach obiger Alkoholmethode auf Gallensäuren untersucht. Im Serum gelang es mir nie, Gallensäuren zu finden, wohl aber in den Corpuskeln.

Um auszufinden, ob die Gallensäuren in den rothen oder den weissen Blutkörperchen zugegen sind, verfuhr ich folgendermaassen: Zwei Doppelligaturen wurden etwa 4 Zoll von einander entfernt um die V. jugularis ext. einer Kuh gebunden und das zwischen den 
beiden Ligaturen gelegene Stück Vene excidirt. Hängt man ein solches Stück Blutgefäss vertical bei niedriger Temperatur auf, so wird die Gerinnung des Blutes verhindert und die Blutkörperchen, dem Gesetze der Schwere folgend, sinken zu Boden. Unter günstigen Umständen lässt sich auf diese Weise sogar eine Trennung der rothen und weissen Zellen bewerkstelligen. Sticht man mit einer Pravazspritze in den alleruntersten Theil der suspendirten Vene ein, so gelingt es fast immer, nur rothe Blutkörperchen zu aspiriren, da die Leukocyten sich in einem höheren Niveau der Zellensäule finden. Untersucht man rothe Blutzellen, die man sich auf diese Weise beschafft für Gallensäuren, nach der Alkoholmethode, so findet man sie nicht.

Da mithin das gesammte Blut Gallensäuren enthält, da aber weder Serum noch rothe Blutkörperchen solche anfweisen, so sind wirscheinbarzu dem Schlusse berechtigt, dass die Gallensäuren thatsächlich in den Leukocyten vorhanden sind. Ehe eine Methode entdeckt wird, weisse Blutkörperchen in grösseren Mengen aus dem Blute darzustellen, muss die endgültige Entscheidung dieser Frage noch ausbleiben. Die Leichtigkeit jedoch, mit der es gelingt, in der leukocytenreichen Flüssigkeit des Ductus thoracicus (siehe oben, Tappeiner) Gallensäuren aufzufinden, spricht entschieden für unsere Auffassung.

Ueber die physiologische Bedeutung dieser geringen Mengen Gallensäuren im normalen Blute zu speculiren unterlasse ich; es mag nur daran erinnert werden, dass Gallensäuren selbst in so kleinen Mengen die folgenden Wirkungen, theils in vitro, entfalten können: 1. wirken sie cytolytisch, besonders für rothe Blutkörper, 2. wirken sie als Cholagoga, 3. beschleunigen sie die Blutgerinnung, 4. wirken sie als Vasodilatoren. $\mathrm{Ob}$ sie physiologischer Weise in diese Processe eingreifen, bleibt noch dahingestellt und muss erst durch weitere Untersuchungen gelehrt werden. 


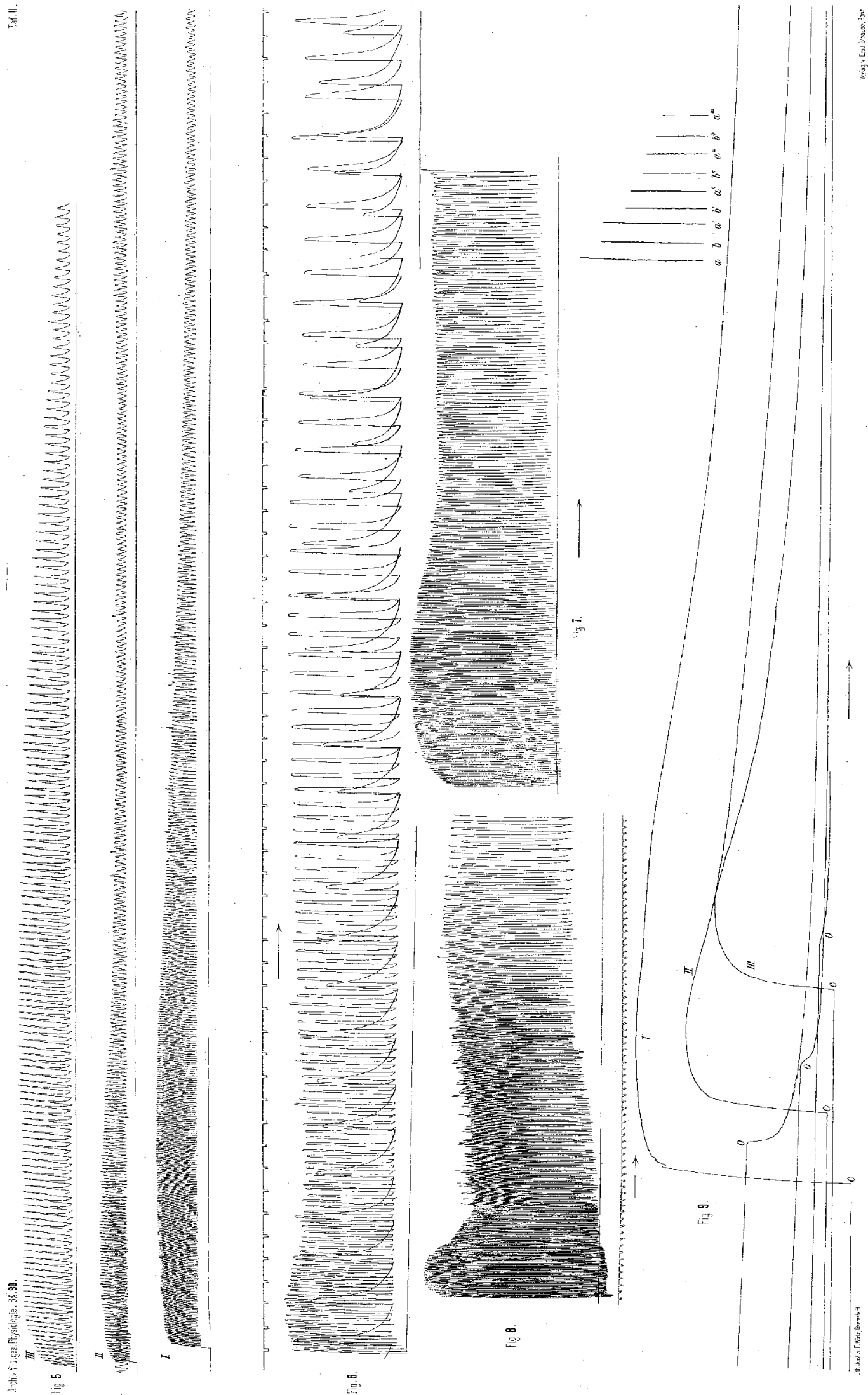




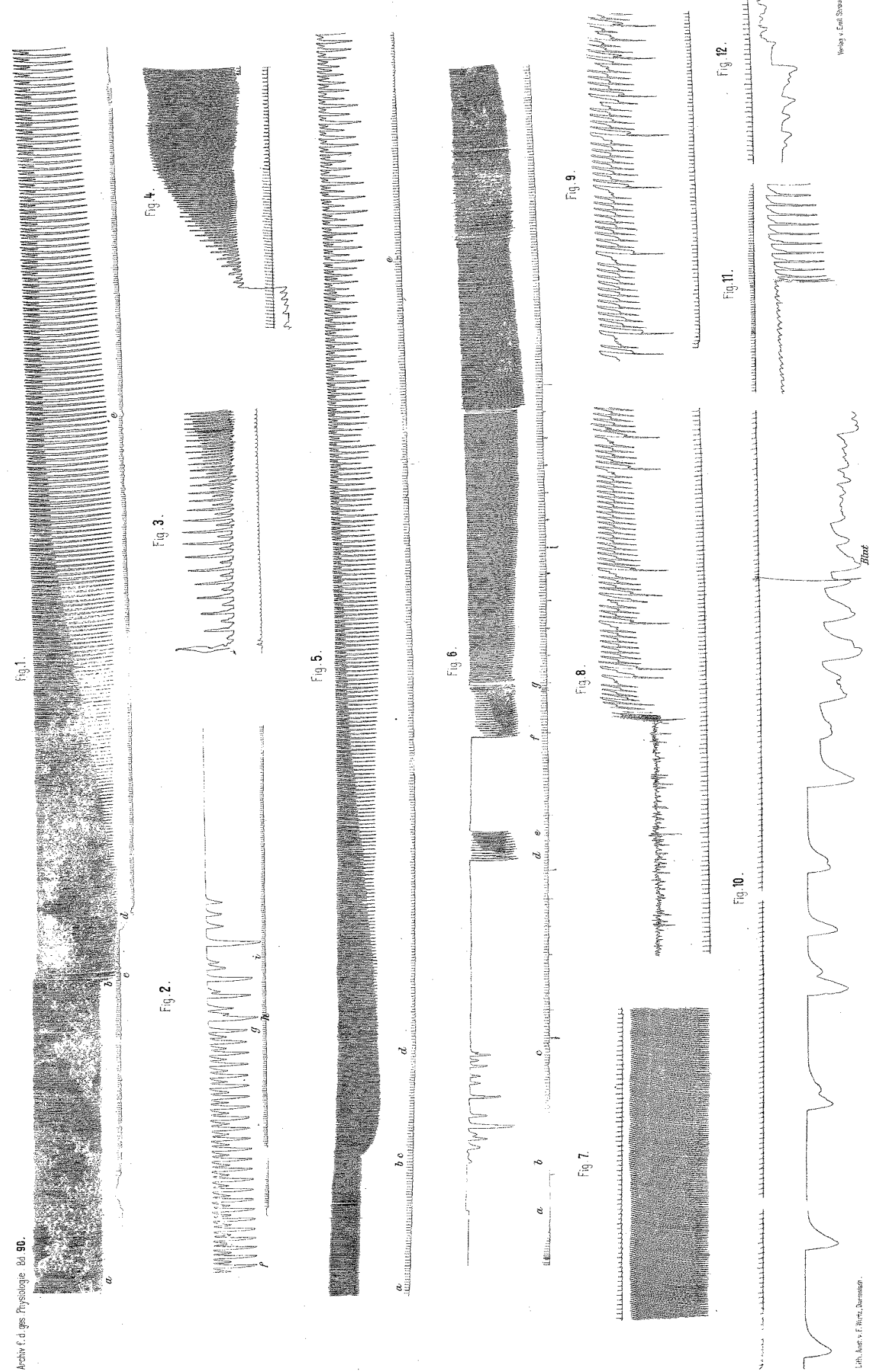

